\title{
A Philosophical Reflection about Ethics and Corporate Social Responsibility
}

\author{
Ronie Alexsandro Teles Silveira ${ }^{1}$, Francisco José Costa ${ }^{2}$, Henrique Muzzio ${ }^{3}$
}

Universidade Federal da Paraíba - e-mail: roniefilosofia@gmail.com

${ }^{2}$ Universidade Federal da Paraíba - e-mail: franzecosta@gmail.com

3Universidade Federal da Paraíba - e-mail: hmuzzio@bol.com.br

\section{KEYWORDS}

Ethics;

Social responsibility,

Responsibility,

Administrative practice,

Management.

Received 23.07.2015

Revised 20.04.2016

Accepted 20.05. 2016

ISSN 1980-4431

Double blind review

\begin{abstract}
This article discusses the philosophical foundations of business ethics and corporate social responsibility, from a critical conception of the approaches commonly used, their assumptions and their justifications. The paper presents a theoretical and philosophical reflection, developed in order to question and appoint alternative solutions to the weaknesses of the most common justifications of corporate social responsibility. These discussions, according to the argumentative construction of this article, culminate in the proposition of four elements to be considered in a stronger debate about the theme: the ethical personality of organizations; ethics community; the liberty; and the identity between ethics and interest. These elements bring in themselves a different agenda for the debate on responsible business, corporate responsibility, business ethics and social ethics. By considering the ideas proposed in this article, management professionals and students, as well as researchers from the general areas of management will have differentiated and complementary references to the pre-existing ones to a understanding better a more consistent and well justified definition of an ethical and socially responsible company, going beyond current and sometimes fragile justifications which are, sometimes, social and academically discredited, as is the case with justification of the strategies of social responsibility from the argument that it generates profits for companies.
\end{abstract}

\section{Introduction}

The most recent global financial crisis, which started in 2008, has expanded discussions involving elements of the economic, political and social spheres in the search for explanations of its causes and its possible consequences. The world witnessed actions of unprecedented proportions that were taken by governments of great powers to try to reestablish the capitalist order at the cost of billions of dollars.

At the same time, some specialists questioned the ability of this economic system to ensure its functioning within the rules of the conventional game that has been played for two centuries (incidentally, a game which is heavily criticized by those who say they are deprived from their benefits, such as the Occupy movement in the United States and the Los Indignados movement in Spain). That is the result of a larger debate in the early twenty-first century, when the global society, devoid of references to action, sought alternatives to a model of economic and social development which was inspired by the ideas of the Enlightenment (Lipovetsky, 1992).

These discussions include the issue of 
production and consumption of goods and services and imply a debate in the business context of what is, or is not, valid, ethical, and socially responsible. In Brazil, it is in this context that debates about ethics and social responsibility have gained breadth, becoming an essential topic in corporate discussions, in management education activities, in business forums, and in business media ever more intensely, comparing the movements around the subject which have developed since the 1990s (although the studies and business discussions on ethics and social responsibility come from de 1950s).

These questions reverberate in the academic context through the demand for a knowledge organization on the subject, and by the challenge of building a substantive theory on it. There are some theoretical perspectives being effectively used to support concrete problems; however, it is not difficult to observe that analysts are still beginning discussions on the subject, without a solid foundation that enables a definition of common parameters about the debate to be conducted. Thus, we understand that the main deficiency of the current situation about corporate ethics and social responsibility is the lack of conceptual references which establish the initial and common basis for a more robust theory (we acknowledge that there is a conceptual difference between ethics and social responsibility, and that even the latter is a form of manifestation of a successful implementation of the first; however, taking into account the discursive practice, and the theoretical and pragmatic convergence, here we decided for the treatment of the two topics under the same perspective) .

In this essay, ethics and social responsibility are understood as socially validated behaviors and, as such, full of moral assumptions that are appropriate for an institutional and disciplinary discussion (Dimaggio \& Powell, 1983; Suchman, 1995) that attempts to direct human and organizational behavior. But the view defended here is that there is a confusion of terminology and principles in the academic and business debate on the subject, which is due to the very nature of the philosophical and moral content involved, which, in our view, still requires further consideration to generate a better comprehension of practices and alternatives.

For example, it is not uncommon to find lists of moral advice disguised as discussion about ethics and social responsibility, as if they, even when well intentioned, could solve the problems generated by contemporary situation; this makes such advice questionable despite the fact that, because they belong to the universe of consulting and economic journalism, they do not need to worry about the theoretical state of the questions addressed in councils and journalistic coverage on the subject. For us, only a more solid foundation will enable the overcoming of potential failures like these, making it possible to overcome forms of moral proselytizing in management discourse and practices. Indeed, offering moral advice conveys the idea that the concept of ethics has been duly clarified, because only this concept can give rise to moral actions. That is, such advice seems to assume there is already a consolidated theory coming from a socially established practice, which is certainly not the case of the debate on ethics and corporate social responsibility, at least in the way in the Brazilian academic and professional contexts.

Another example of the failure of typical conceptual definition existing in the literature concerns the relationship between morality and profit. About this subject, there are extreme alternatives of two types. One, based mainly in the arguments of Friedman (1970), who affirms that there is incompatibility between these elements and, therefore, the impossibility of defining ethics and corporate social responsibility as a solid field of studies. Thus, ethics and corporate social responsibility would be just ideological instruments of opportunistic capitalism (see section 2.2). The other, more grounded in the latest theories of Management, argues that it is possible, to reconcile these concepts and that a theory on the subject is not only possible, but also desirable in spreading the benefits of the companies to their stakeholders.

What draws our attention in both perspectives is that they have failed to conceptually solve this apparent difficulty, and the people involved are only invited to decide for only one or the other policy alternatives through subjective appeal. As an example we can mention the manuals of ethics and social responsibility used in undergraduate Business Management courses, which adopt the second position, but hardly discuss the foundation of business morality and the contents are disperse into historical aspects, in examples, and in various cases. What

Revista de Negócios, v. 20, n. 3, p. 16-27, July, 2015. 
follows, then, is just a statement of this prior decision, and a reaffirmation of assumptions assumed from the beginning of the analysis.

We try to meet our objectives putting together the our ideas, readings and evaluations from a Brazilian context, although owe intention is not to propose a Brazilian theory, neither a theory for Brazil. Also, it is worth noting that, by the state of the art of the theme and the space available for the article, there is no presumption of proposing a definitive philosophical theory of ethics and social responsibility; we just intend to present a well-grounded reflection, with some ideas of possible alternatives for any hitches of the discussion on the topic.

\section{Some (almost) dominant prospects and discourses}

This item focuses on a schematic characterization and an analysis of the three most evident perspectives in the academic literature about ethics and corporate social responsibility, which are: the moralistic perspective, the sociological/historical perspective, and the administrative perspective.

\subsection{Ethics and corporate social responsibility as moral imperatives}

Moralism is understood here as a type of discourse that tries to convince the social actors to act in accordance with certain principles which are considered ethically correct by a person or a group. In the context of business administration, the moralist discourse manifests itself in expressions like the businessman must..., the leader must... and the company must.... Expressions and catchphrases like these are commonly present in the discourse of some professors, lecturers, journalists, and writers from the world of business. In these uses, the moralist discourse functions as a set of 'golden rules' that, if followed by those who are interested, ensures that actions are fully imbedded in an ethical and socially responsible nature.

At least since Moses and his Tablets of the Law, moralism is well known in the debate about ethics, especially by its tendency to reduce morality to a clear set of commandments that must be obeyed by all people. Its logic is simple: following the recipe that he offers, the problem of how to act in specific situations will be solved.
Besides being simple, the underlying logic of such speech is clearly fragile, because of the low level of this discourse effectiveness in terms of generating practical attitudes.

Moralism may seem effective to an entrepreneur who has the urge to add value to his or her product through an 'ethical label' valued by the market. Thus, by following the set of commands provided by 'priests of morality', the entrepreneur believes to be adopting a more ethical stance. However, from a concrete point of view, moralism is not effective because it simplifies matters and leaves out everything that is more problematic. In this case, moralism is concerned first about the appearance of ethical actions than about ethics itself.

Thus, through providing moral rules of simple content, the 'corporate Moses' presents himself as a defender of a common sense. He does not lead to any understanding of his own criteria of ethicality which, incidentally, he states in the advice he gives. That is, moralism is characterized by having a common point of view that is unwilling to question the bases that ensure value to its set of rules.

Certainly, intention underlying moralistic advice can be pure and almost holy. For example, a moralist might say that an ethical entrepreneur should not cheat their customers. This seems to be ethical and even unquestionable. But while displaying this line of action, the moralist leaves out what is most important: why cheating would be reprehensible? In the exploration of this example, we can question whether there is a difference between an intentional cheating and a mistake. Would unconscious cheat be ethics? If an entrepreneur acquires a deteriorated raw material, ignoring this fact, and turns it into a bad quality good that will be sold later, is it cheating customers? Should not they be responsible for quality control of raw material? And, knowing about the lack of quality of the raw material at a later time, would it be ethically necessary to inform the problem to customers? More generically: are inadvertent mistakes immoral actions? These issues are not always reflected in the moral universe, as it describes the ethical issues at their most superficial and immediate aspect without questioning what is part of the complexity of concrete human actions.

In fact, the strong presence of moralism in the business world is the result of its own 
superficiality. It is easy and inviting because it simplifies; but, in this case, simplifying is eliminating the core of corporate ethical problems. Moralism will never provide reasons why actions that it advocates would be possible in a market context.

For example, whenever it is possible, a company uses sophisticated and targeted advertising resources to generate more demand, arguing that its product is superior to others. The advertising argument can be false because it promises things that are not necessarily true. However, it is validated in the market context, given the current stage of advertising technologies development. About that, a 'corporate Moses' would say: do not deceive your customers without specifying what that means in this context.

There is, in the above example, a question that remains unanswered in the moralist discourse: why should not a businessperson deceive their customers? Why does a businessperson have to give up on their own interest? In other words, why must we be ethical or not when meeting interests means offering what is not necessarily granted by us? Without answering this, the question of ethics and corporate social responsibility comes down to the observance of the rule by the rule, since there is no reason why this particular rule should be object of respect by the agents. The authority of the 'moral priest' derives from the fact that he or she considers to be solved what has not been solved; therefore, this authority is fictitious, and anyone can climb an ethical pulpit and start a form of preaching. The question is about knowing why this is the pulpit that gives the authority to the preacher and not to any other person. Without this, we think that the ethical discourse has no value.

We believe that moralism can make the ethical problem superficial and potentially create more problems than solutions. Thus, although it is a discourse that provides easy and immediate answers, they have no durability and have a tendency to deteriorate rapidly in some form of pharisaism. For this reason, we understand that a conceptual discussion of ethics and social responsibility should start by avoiding the easy path of moralism. No set of rules will solve the problem of complexity of human actions in corporate environments.
2.2 Ethics and social responsibility as historical and sociological consequence

A second perspective of the discourse on ethics and corporate social responsibility is what you might call 'sociological and/or historical perspective'. This line of thinking is concerned with analyzing the emergence of an entrepreneurial mindset oriented by ethical aspects and to meet social interests. Thus, it seeks to explain the concern with ethics as a response to current demands, such as the new demands of globalized markets, increasing consumer awareness, competitive intensification, the unavoidable presence of information and communication technologies, and so on.

This perspective can then be characterized as an essentially suspicious discourse in relation to the concerns with ethics and corporate social responsibility, because it understands discourse as a direct result of specific social and historical conditions, linked to the economic, social and technological base. Just by understanding that the concern with ethics and corporate social responsibility is a form of consequence, the sociological and historical discourse seeks to identify its causes, but it does not go deep into its specific nature.

It is understood that by reducing the question of ethics and corporate social responsibility as being motivated by a concern to economic and historical issues, this perspective deprives them of their right to existence. As it presents itself as a reflection of economic and political conditions, we understand that ethics and corporate social responsibility cannot be treated separately, as a stand-alone instance. That is, issues of ethics and social responsibility are reduced to consequences of sociological and historical movements, they are ideological responses related to capitalism strictly oriented to the economic outcome. As such, they are deprived of the possibility of being understood as a field of study which has an epistemological legitimacy that can be understood from its very bases. Like any form of ideological discourse, this should also be the subject of a review which will show what you want to hide (cf. Marx, 1988). In this case, the component underlying ethical and ideological discourse is certainly the search for profit and the maintenance of competitive conditions demanded by the market.

This is not a reflection of the issue of 
morality with traditional deontological (the action for its own value) and teleological (the action for its purposes) discourses. In this perspective, morality cannot even be thought in itself, because it is the result of social movements and the innovations in market evolution. For sociological and historical overview of ethics, what is new is only the corporate response to current economic and social conditions, and the correct understanding of this answer lies in the apprehension of its causes. What matters to this perspective is not, properly speaking, ethics, but the social and economic causes that move corporations to try to become more ethical.

There is something wrong with this discourse on ethics and corporate social responsibility. Taken to the extreme of a sociological and historical determinism, almost all phenomena of the world can be explained from the same view. But that is not in accordance with what is set as a goal: to make a theoretical platform possible so that it fosters the selfdevelopment of problems related to ethics and to the corporate world. Accordingly, the sociological and historical perspective is not sufficient since it contributes to just a partial understanding of the issue.

We believe that knowing a phenomenon means not only connecting it to its social and historical causes, although this information will certainly help in the understanding. It is agreed that to know is to understand certain phenomena within the context of their specific complexity. We must take into account its novelty: what constitutes its positive character and what makes it distinct from other manifestations of the past. Reducing a phenomenon to a set of known causes is a triviality that repeats the same formal scheme (in that, with it, it just loses its specific color and becomes equal to all others). We should not believe 'all cats are gray in the dark'.

In sum, although we acknowledge the existence of a historical and sociological component in the configuration of discourses and actions developed around or on behalf of ethics and corporate social responsibility, we can say that the autonomy we are seeking for the subject is not legitimate because the whole issue can be summarized in the need of addressing the increasing openness of the world markets. Accordingly, there is no need of any new conceptual basis for the issue of ethics in corporate environment, and good causal sociological studies can end up the problem. Against this, it is argued that the sociological aspects are not the whole issue, although an important one. The demonstration of this statement will be given if here we manage to indicate non-sociological dimensions involved in the topic of corporate ethics; that is, the autonomy of the object of this study will have to be demonstrated through the pointing out of elements that cannot be reduced to historical causality.

\subsection{Ethics and social responsibility as} administrative practice

The problem of ethics and social responsibility is also presented within the field of management studies, probably the context in which the subject is discussed the most. It is widely known that the field of management is far from building an analytical homogeneity that allows the interpretation of the subject evenly. Historically, this plurality has been fed by the performance/structure, constructivist/positivist, local/global, individualist/collectivist debate (Reed, 1998). The predominant component of the administrative point of view, the functionalism, when occupied with the analysis of ways of generating competitive advantages for the company, included the ethical concerns throughout the production and consumption process. Thus, we seek primarily to create a strategic value in the mindset of consumers, so that ethics and social responsibility have become additional characteristics of goods and services. This provides a company, one supposes, their differentiation from competitors, and a sustainable competitive advantage by exploiting these elements (Barney, 1991), as well as by the association of the latter to a composition of forces in an industry or economic sector (Porter, 1985).

The management literature is certainly the most ambiguous of the set under review, as it oscillates between an open utilitarianism and some form of humanism. This becomes noticeable by the adoption of ideas rooted in functionalism and ideas associated with postmodernism (Cooper \& Burrel, 1998), or even when defending themselves, on one side as an instrumental rationality (Weber, 1999) and on the other as a substantive rationality (Ramos, 1981). That is, it can either focus on the issue: a) under the purely instrumental bias (realized, for example, in 
announcements of missions and visions of the future of the strategic plans or in the actions of commercial advertising); b) under the moral bias with the aim of developing concerns with ethical values in an authentic way. This dichotomy is an emerging clash between an ideal of corporate responsibility and the distance of this in the context of corporate practice (Cragg, 2012).

Indeed, the literature on administrative ethics and social responsibility fully assumes the very ambiguity of the issue of corporate ethics: how do we associate an ethical value to a good or a service? Does the association of this 'additional value' means a change in the level of consumer beliefs, creating the belief that something more was incorporated to the product? In this case, it would be, above all, a strategy of persuasion. Or, on the contrary, does the addition of this value implies a change in the production system and consumption - in any change made as a recognition of the importance of ethics?

In the Brazilian context, empirical researches have emphasized the ambiguity of how this issue is handled. Borges, Medeiros and Casado (2011) analyzed the relationship of ethics with business competitiveness from the view of management students, and the results suggested the ambiguous and contradictory symbolic opinion of students in relation to the manager's role and in relation to the practice of proper management in this context.

The literature about management is very illustrative with respect to this ambiguity that permeates the whole issue of ethics and corporate social responsibility (Arnold, Audi \& Zwolinski, 2010). In fact, ethical concerns, when considered as genuine and given a high value, seem to lead to a cooling of the search for results, and not a search intensified by the prospect of more competitive advantage.

The analysis of the literature on the subject seems to indicate that ethics is only welcomed when it brings effective results for organizations. If so, then this concern is a strategic move to expand corporate results and implies no real change in the processes of production and consumption. This helps to understand the discourses that seek to show that ethics and social responsibility are necessary to businesses, as customers can pay more, or human resources departments can make workers more motivated. What is hidden is of course the opposite question, namely: What if customers do not pay more? And what if workers do not work harder? Are ethics and social responsibility no longer necessary?

Although it is not necessary here to continue with this characterization, a difficulty is taken as evidenced from the perspective of management. Although having a large contribution to the understanding of the subject, this perspective is partial and fragile as a proposal to suggest concrete resolutions. This explains why this managerial literature is ambiguous in its concern with ethics and social responsibility, at least in the Brazilian context. Probably, this difficulty, which is within the scope of corporate ethics itself, is derived from the contradiction that seems to characterize the subject by comparing interest and ethics.

\section{A philosophical perspective of ethics and the corporate social responsibility}

In the research undertaken by the authors, it was identified a big philosophical literature on ethics and corporate social responsibility, including many books and academic journals with many articles published each year. Specifically in Brazil, we identified some books and articles dealing with the subject, most of them developed by authors associated with the administrative perspective, such as Ramos, Arruda and Whitaker (2005), and Ashley (2005). However, we believe that for this literature, a better conceptual basis is still necessary for defining and solving some fundamental problems

With this construction, we think that a substantive theory of ethics and corporate responsibility will propose basic conceptual problems so that solutions may prove viable. So, here we present and discuss briefly some basic elements that we consider are necessary to constitute philosophical discussion of ethics and corporate responsibility (not a moralist, a historical and sociological, nor a managerial discussion). This is not, of course, an exhaustive list, but a set of elements that need to be introduced in a future theory on the subject. We anticipate that it is possible that some features of these elements are shared with the other perspectives. In this case, what is characteristic of this theory is the way it presents and attempts to solve the problems derived from such elements. 


\subsection{The ethical personality of the company}

One of the key issues that a philosophical discussion of ethics and corporate social responsibility must try to answer is: why should an organization be ethical and socially responsible? There are instrumental responses to this question, but that would probably lead directly to the administrative level and for an obvious answer: because it generates higher performance. However, by responding that way, we would affirm that the bond between organization and ethical duty is exterior to the company. We analyze now, in more detail, the meaning of externality of duty.

A business organization has a widely accepted operating logic, which is making a profit for shareholders. Generally, it is stated that it should also adopt good ethical values. Thus, these ethical values would be added to the pre-existing in the form of the expression business logic 'also'. And, it is precisely this expression that characterizes the externality of ethical value with respect to the logic of organization, because everything that is related in the form of an 'also' is something added from outside, which is juxtaposed, but to which does not constitute an organic link. If the intention of a business is to generate profit, so 'also' being ethical and having social responsibility is an adjunct to the primary intention, which is to generate results for shareholders.

Being exterior and only an adjunct, the link between ethics action and business logic may or may not occur because suppressing one does not mean suppressing the other. As they are only juxtaposed, an action on one does not necessarily imply an action on the other. Thus, depending on a strategic assessment of market conditions, the interference of personal values of managers or of other factors, ethics could be dropped out without prejudice to the primary function of a business organization.

Thus, the basis for ethical action is always dependent on an economic decision of one or more actors, but is not organically linked to an intrinsic need of the organization itself. In other words, the link between duty and organization takes place under a contingent mode (this reinforces why we understood that the sociological/historical and the managerial approaches are fragile, since by them, if the context changes, ethics and social responsibility intention changes, but the profit intention is maintained.). This characterizes the absence of organicity between the business logic and ethics and, therefore, the lack of solidity of duty: ethical actions may or may not be adopted, depending on the convenience or the context of each organization.

We understand, therefore, that the contingency undermines the ethical aspect of decision making, in that it establishes an outside relationship with the values adopted. An analysis of the main models of ethical decision making shows this (Ferrel et al., 2013). If the values are aggregated to pre-existing organizational logic in the form of an 'also', ethics will not have an actual existence, let alone effectiveness, as it will have its condition of existence defined according to the convenience of the moment.

This indicates that companies do not need to be ethical or socially responsible because it is their nature to be just as it is their common nature to seek profits for its shareholders. By the restricted view of profit, the understanding of Friedman (1970) that a company does not need to have social responsibility other than to making a profit (because the profit already has social value) is unquestionably correct. According to Friedman, the adoption of ethical and socially responsible measures will generate more costs, which undermines the logic of firm's efficiency, and some agent of the exchange system must pay this additional cost. Ethics would be a kind of inefficiency, since its cost would be paid by the consumer, who is the most vulnerable part of the exchange system.

The relationship which is stated here between ethical action and the interiority of duty cannot go unnoticed. We understand that one of the bases for the reasoning of a corporate ethics is precisely this organicity between ethical values and business logic. The moralistic view insists, simply, on the need for values to be assimilated by the company. We do not propose this understanding; we believe that the values must become part of the essence of companies themselves. This merger should occur in such a way that it is no longer possible to understand the company without its ethical values, and this company will not be able to operate without its actions being a reflection of these values: what it is will mean a way of acting ethically. With that, it will have acquired an ethical personality.

Revista de Negócios, v. 20, n. 3, p. 16-27, July, 2015. 
But ethics and corporate social responsibility should involve an organic change in the company, so that it has an ethical personality, in a way that its mode of being can no longer be disconnected from its mode of acting. Thus, a theory of ethics and corporate social responsibility cannot go without dealing with the transformation process of an organization that considers ethics under an instrumental perspective into another that cannot exist without adopting specific values. That is, it must explain how corporate ethical personalities can be generated. The process of incorporation of ethical personality by companies is a first major theoretical challenge that needs to be subject to a robust theory on ethics and corporate social responsibility. Without it, the duty will maintain its external aspect.

\subsection{The ethical community}

It is understood that ethics and corporate social responsibility are attributes of a collective, rather than a single entity. Thus, a difficulty for understanding it is related to the collective nature of this ethical modality. This is not an ethic that has its basis in the individual, but a collective entity that aggregates a set of individuals. This aspect makes a difference when trying to understand how corporate ethics works.

To facilitate the understanding of this aspect, it is possible to take a glimpse on Ancient Greece followed by an abrupt return to our days. The ancient Greek city-state was characterized as a collective ethic identity, based on the overlap of religious, ethical and political values (Coulanges, 1905). Thus, fouls against the duty were understood as religious faults and simultaneously as fouls against the state. The penalty called ostracism (a kind of exile) was to deprive a citizen of their political participation, religion and humanity - as a foreigner could not be a citizen in another city. This means that there was no value to a man out of his ethics community and removing him from this context was a punishment even more severe than death. The whole being of a person was in connection with his/her location and the set of values of his/her community. Without them, the person would be stripped of his/her humanity (that meant ostracism).

In the contemporary world we give up on ordering our personal lives under metanarratives (Lyotard, 1979), which are the major theories that give meaning to life and guide us through permanent references. Nowadays, we live in a world marked by an intense individualism and a form of increasingly acute privacy. In this context, people are worth for themselves and not because they are citizens of some country or because they share beliefs with other people - as the followers of a religion. They are a person because they are an individual and not because they are part of something broader that includes other individuals or share values. The fact that we cannot share most of our beliefs with others does not affect our humanity, and even when we assert our independence acutely, we are not separated from something greater than what is essential to our human condition. It is possible to disagree and criticize almost everything and yet, we still have the right to do so.

Given the descriptions of Coulanges (1905) and Lyotard (1979), we note, however, a radical change in the way the ethical references are experienced in the ancient world and nowadays. To an ancient Greek person there was almost no alternative between being ethical or not, because not being ethical meant a sin, a political crime and disobedience to the basic rules of human society. For them, not being ethical meant undermining their own humanity. However, for a contemporary person, the ethical space is much larger. We experience a diverse environment in which it is not necessary to have stable or homogeneous references. We may assume different values in different circumstances, also due to the multifunctionality of the social roles we play. As we have several functions, we can adopt various kinds of values (Lipovetsky, 1992).

If this is indeed our ethical condition of existence, how can an organization propose to adopt common values which are necessary for the establishment of its ethical personality? How can shared ethical values be shared in a context of excessive individualistic fragmentation? The Lyotard's (1979) description of the postmodern condition is certainly a historical environment in which the task of sharing common references has become a challenge that must be considered with special attention. It makes no sense to propose ethical values assuming relative ease in obtaining credit for them in face of several autonomous individuals. Indeed, a world characterized by unrestricted value of the person makes coercion and ethical conviction much more difficult to be realized. Our society is extremely heterogeneous

Revista de Negócios, v. 20, n. 3, p. 16-27, July, 2015. 
and democratic, which makes the possibility of collective beliefs to be smaller than any other known historical context.

But the possibility of establishing an ethical community is a prerequisite for the establishment of an ethical personality, that is, for the intrinsic adoption of values by an organization. In other words, without having a group of individuals sharing values and acting according to them, an organization does not possess ethical personality. The establishment of an ethical community is therefore a necessary condition for the transformation of an organization into an ethical personality. The necessary convergence can be difficult in a postmodern context, and this is a challenge for a well-grounded theory and practice based on ethics and corporate social responsibility.

A second step in building a theory of ethics and social responsibility is therefore to understand what actually characterizes an ethical business community in a postmodern environment. Probably, this theory must consider the difficulties present in the sharing of ethical beliefs by individuals living in an extensive ethical space, enjoying an extreme individual freedom.

\subsection{The value of freedom}

In the academic literature there are frequent examples of leaders that establish ethical values through codes, being them written or not. These leaders give an example that is expected to be followed by the other members of the company. But as supposedly free citizens, these members have the option to follow certain ethical parameters or not (of course this freedom is restricted by legal regulations establishing the minimum conditions governing the relationships among the citizens of a society).

However, in situations of organizational hierarchy there is not always freedom for the values to be adopted. Thus, it may happen that an organization adopts ethical values which not everyone agrees with, which can lead to a false assent on the part of fearful-of-losing-their-jobs individuals, something that will result in some form of personal self-righteousness, like the company self-righteousness stated above.

It is understood that it is not possible for an organization to adopt an ethical personality without free individual consent, precisely because the imposition could generate a silent resistance and therefore the lack of organicity of corporate values. The imposition of collective values to individuals is contrary to the principle of individual freedom and undermines the organic nature of the ethical personality required for the realization of a true social responsibility, although it is common in the business instrumental view in favor of a strong cultural unity (Martin, 2002).

In other words, individual freedom should be understood as a fundamental requirement of ethics and corporate social responsibility insofar as values can only be organically assimilated by members of an organization in environments characterized by spontaneous agreement. Therefore, democratic procedures are necessary for the establishment of an ethical personality.

Although this element of the recognition of the political condition in which we live is inseparable from the intense value of the individuality of the previous element, it is understood that it should be treated separately. The previous issue was the difficulty in the ethical convincing of people highly focused in their own individuality. The question now is the recognition of freedom as a necessary condition for that conviction. That is, there will be no ethical personality in conditions of values imposition, which is typical of authoritarian environments and cultures.

In a perspective that escapes the domestic scope of companies, and in a context in which they perform more actions of social responsibility and of ethical behavior, the importance of adopting any of the measures due to free membership, and not by market conditioning (such as competition and quest for competitive advantage) is reiterated. These aspects are commonly thought of as if they were imposed, which common in the historical/sociological and in the administrative discourses is discussed above. Probably, it will be the adoption of practices voluntarily and by a free decision of executives and entrepreneurs that the partial understanding of these perspectives will be able to be denied. They are fragile because they, at the same time, inform the necessity of ethics of corporate social responsibility, and point out that, after the contingency factors that imposes them are over, those are disposable.

3.4 The identity between ethics and interest As previously discussed, when the 
administrative perspective on ethics and corporate social responsibility is presented there is some ambiguity in the literature concerning the interest and ethics. Indeed, the literature varies between strategies to add ethical value to a good or service in an instrumental way and the introduction of effective changes in the production and consumption processes.

Eventually, interest has been stated as something that can and even should be sacrificed in the name of ethics. The other side of this coin also seems to be true: the choice for interest is the negation of ethics. Accusations of bad intent or double intention permeate much of the discussions on the adoption of ethical values for organizations that cannot even leave the interest for results, that is, after all, its rationale and guides their actions (Chamberlain \& Gordon, 1989; Gill, Biger \& Mathur, 2011). As it was mentioned, a socially responsible organization could be a contradiction in some terms, because if it is socially responsible, it will have to stop being what it is in its essence. This way of understanding the problem is even prevalent in the historical/sociological perspective.

However, a conceptual analysis can demonstrate how the apparent contradiction is resolved. The primary interest of a business organization is the result, but it can get better results being ethical and socially responsible. In this case, it also converts its interest in being ethical and socially responsible. But it becomes so only on the basis of a denial of its fundamental interests; thereby, its own interest became disinterest. And it is precisely this lack of interest that potentially enhances the results (the interest becomes disinterest in the adoption of ethical and socially responsible principles and disinterest turns into interest for the final rise of the results).

An organization endowed with an ethical personality can overcome the apparent contradiction between interest and ethics. This seems to be the core foundation of the great discussion on the stakeholder theory, which states that the company must meet the interests of all stakeholders that affect it and are affected by it (Agle et al., 2008; Kacperczyk, 2009; Harrison, Bosse \& Phillips, 2010).

Quite briefly, the stakeholder theory focuses on the challenge of how to produce goods and services creating value for all entities involved directly or indirectly, without causing damage to any agent, while promoting economic development ethically. In this perspective, two major challenges to theorists of this field are: a) how the basic normative of the stakeholder theory can help the field of business ethics to provide useful insights into the ethical management processes; b) as alternatives to the debate, the stakeholders can provide normative reasons for the various agents concerned with the business when the market fails, that is, when the efficient use of resources is not efficiently distributed to society (Agle et al., 2008).

It must be noticed in our view of the ethical personality of the firms; ethics is not exploited as a competitive issue because organizational purpose makes results and ethics identical. It only would be exploited this as a source of competitiveness when intentionality is considered in a conventional point of view, that is, if one thinks that an organization needs to be ethical and socially responsible in order to gain competitive advantage. But this is not the case here.

Considering the perspective of an organization with ethical personality, these elements become identical in all of their actions, because they, while organic activities, eliminated the difference between intention and action. This process is similar to the adoption of characteristics that become internal due to the pressure of the environment. The fact that they have been originated in the exterior does not deprive them from their internal posterior incorporation. In this case, the essence is constituted through interaction with the externality. The identification of the causes, in this case, prevents us from seeing what is specific in the process of internalization of ethics.

Certainly, this does not mean that every organizational action that seeks results will be considered ethical and socially responsible simply because it affirms that it acts selflessly. These elements may even be a possible contradiction in most empirical circumstances, but surely, there is an insurmountable conceptual contradiction between them and that is what a good theory on ethics and social responsibility cannot forget.

\section{Conclusion}

We believe we have established, in part, the specificity of a philosophical perspective for dealing with issues of ethics and corporate social

Revista de Negócios, v. 20, n. 3, p. 16-27, July, 2015. 
responsibility. This specificity is the need to specifically introduce four elements in the theory (even when these elements are present in the existing literature, they certainly are presented in a different way from the one exposed here). These elements are: 1 - the ethical personality of organizations; 2 - the ethical community; 3 freedom, and 4 - the identity between ethics and interest. This means that the presence of ethics in corporate activities implies organic introjections of duty and the establishment of a community that shares the same values as the basis of a personal free decision. Moreover, a theory on the subject needs to eliminate the false contradiction between interest and ethics. Without this last component, discourses constantly oscillate between the naive or cynical belief and skeptical distrust. So, it is the appearance of the intention of being insurmountable that needs to be abandoned.

Apparently, there is a weakness in the discourses that focus on putting ethics and social responsibility as a differential factor of a particular corporation. Instead, it should be granted that ethical behavior is a condition of existence of a corporation. That is, ethics should not be seen as managerial, at the discretion of certain leaders with instrumental and marketing purposes, but it should be incorporated into the very nature of the firm in an institutionalized position.

In this sense, the study of effective conditions for the establishment of an ethical personality by organizations is the touchstone that allows it to overcome this unilateralism present in the mistrust and ingenuity. That is because the ethical personality that makes it possible to adopt a conceptually higher point of view, to the extent that surpasses the old distinction between appearance and reality, or between intention and action of the organizations. Therefore, it seems clear that future investigations must be developed considering these conditions, may it be from a conceptual point of view, or from an empirical point of view.

We emphasize that the view discussed here have the purpose of suggesting elements of a reasoned debate with preliminary exposure of components of a theory of ethics and corporate social responsibility, but not with the purpose of building up this theory. As indicated, our purpose was not to establish a theory, but to bring elements of a philosophical discussion in searching of pinching new theories.

\section{References}

Agle, B. R., Donaldson, T., Freeman, R. E., Jensen, M. C., Mitchell, R. K., \& Wood, D. J. (2008). Dialogue: Toward superior stakeholder theory. Business Ethics Quarterly, 18(02), 153190.

Arnold, D. G., Audi, R., \& Zwolinski, M. (2010). Recent work in ethical theory and its implications for business ethics. Business Ethics Quarterly, 20(04), 559-581.

Ashley, P. (2005). Ética e responsabilidade social nos negócios". São Paulo: Saraiva.

Barney, J. (1991). Firm resources and sustained competitive advantage. Journal of management, 17(1), 99-120.

Borges, J. F., Medeiros, C. R. D. O., \& Casado, T. (2011). Práticas de gestão e representações sociais do administrador: algum problema. Cadernos Ebape. BR, 9, 531-563.

Chamberlain, T. W., \& Gordon, M. J. (1989). Liquidity, profitability, and long-run survival: theory and evidence on business investment. Journal of Post Keynesian Economics, 589-610.

Cooper, R., \& Burrell, G. (1988). Modernism, postmodernism and organizational analysis: An introduction. Organization studies, 9(1), 91-112.

Coulanges, F. (1905). La cité antique: étude sur le culte, le droit, les intitutions de la Grèce et de Rome. Paris: Librairie Hachette.

Cragg, W. (2012). Ethics, enlightened selfinterest, and the corporate responsibility to respect human rights: A critical look at the justificatory foundations of the UN framework. Business Ethics Quarterly, 22(01), 9-36.

Dimaggio, P. J., \& Powell, W. W. (1983). "The iron cage revisited: Institutional isomorphism and collective rationality in organizational fields". American sociological review, 48(2), pp.147-160. Ferrell, O. C., Crittenden, V. L., Ferrell, L., \& Crittenden, W. F. (2013). Theoretical development in ethical marketing decision making. AMS review, 3(2), 51-60.

Milton, F. (1970). The social responsibility of business is to increase its profits. New York Times Magazine, 13, 32-33.

Gill, A., Biger, N., \& Mathur, N. (2011). The effect of capital structure on profitability: Evidence from the United States. International Journal of Management, 28(4), 3.

Ramos, A. G. (1981). A nova ciência das 
organizações: uma reconceituação da riqueza das nações. Rio de Janeiro: FGV.

Harrison, J. S., Bosse, D. A., \& Phillips, R. A. (2010). Managing for stakeholders, stakeholder utility functions, and competitive advantage. Strategic Management Journal, 31(1), 58-74.

Hegel, G. W. F. (1807/1992). Fenomenologia do espírito. Petrópolis: Vozes.

Kacperczyk, A. (2009). With Greater Power Comes Greater Responsibility? Takeover protection and corporate attention to stakeholders. Strategic Management Journal, 30(3), pp.261285.

Lipovetsky, G. (1992). Le crépuscule $d u$ devoir. Paris: Gallimard.

Lyotard, J.-F. (1979). A condição pósmoderna. 7. ed. Rio de Janeiro: José Olympío.

Martin, J. (2002). Organizational Culture: mapping the terrain. Thousand Oaks: Sage Publications.

Marx, K. (1988). O capital: crítica da economia política". 12. ed. Rio de Janeiro: Bertrand Brasil.

Porter, M. (1985). Competitive advantage: creating and sustaining competitive performance. New York: Free Press.

Arruda, M. C. C., Whitaker, M. c., \& Ramos, J. M. R. (2009). Fundamentos de ética empresarial e econômica. Atlas.

Reed, M. (1998). "Teorização Organizacional: um campo historicamente contestado". In: Clegg, S., Hardy, C. \& Nord, W (Org.) Handbook de Estudos Organizacionais (v. 1): modelos de análise e novas questões em estudos organizacionais. São Paulo: Atlas, pp. 61-98.

Suchman, M. C. (1995). Managing legitimacy: Strategic and institutional approaches. Academy of management review, 20(3), 571-610.

Weber, M. (1999). Economia e Sociedade: fundamentos da sociologia compreensiva (v. 1). Editora Universidade de Brasília. São Paulo: Imprensa Oficial do Estado de São Paulo. 